\title{
MODEL PENDAMPINGAN UMKM PENGOLAHAN HASIL LAUT DENGAN METODE PENDEKATAN PENDAMPINGAN TERINTEGRASI
}

\author{
Yeni Priatna Sari \\ Program studi DIIIAkuntansi \\ Politeknik harapan bersama tegal \\ e-mail:yeni.priatna@gmail.com \\ Ida Farida \\ Program studi DIIIAkuntansi \\ Politeknik harapan bersama tegal \\ Hetika \\ Program studi DIIIAkuntansi \\ Politeknik harapan bersama tegal
}

\begin{abstract}
Abstrak
Penelitian ini bertujuan untuk mencari format pemberian pelatihan dan pendampingan yang tepat untuk Usaha Mikro Kecil dan Menengah yang ada di Tegal. Metodologi penelitian yang digunakan adalah metode deskriptif kualitatif dengan mengambil data primer berupa wawancara dengan responden serta data sekunder dari laman kementerian Koperasi dan UMKM dan laman lain nya. Hasil dari penelitian ini diharapkan dapat memberikan masukan kepada pemangku kepentingan dalam hal ini ini adalah pemerintah dalam upaya pengembangan UMKM di waktu yang akan datang.
\end{abstract}

Kata kunci : pendampingan UMKM, Pendampingan terintegrasi

PENDAHULUAN 
PENDAHULUAN

Perkembangan UMKM Indonesia yang saat ini belum menunjukkan perkembangan kesiapan dalam menghadapi pasar global. UMKM memang menjadi unggulan Indonesia dalam skala nasional, namun masih perlu ditingkatkan untuk skala internasional. Jumlah UMKM Indonesia mencapai 95\% dari jumlah perusahaan di Indonesia, dan menyumbangkan $56,92 \%$ terhadap GDP nasional. Namun demikian, sumbangan UMKM terhadap ekspor baru mencapai sekitar 14,6\% (Ashariyadi, 2016)
Pendampingan pada UMKM diperlukan sebagai sarana peningkatan kapasitas bagi para pelaku UMKM terutama dalam menghadapi persaingan yang semakin meningkat.(Ardiana, 2010) Selain itu untuk meningkatkan daya saing UMKM dan agar dapat menguasai pasar, maka UMKM perlu mendapatkan informasi dengan mudah dan cepat, baik informasi mengenai pasar produksi maupun pasar faktor produksi untuk memperluas jaringan pemasaran produk yang dihasilkan oleh UMKM (Sudaryanto, Ragimun, \& Wijayanti, 2014). Oleh karena itu perlu dicari format yang tepat dalam memberikan pendampingan yang tepat kepada para pelaku UMKM. Penelitian ini disusun karena melihat adanya fenomena di lapangan dalam hal pemberian pelatihan kepada para pelaku UMKM yang tidak mengena sasaran. 


\section{METODE PENELITIAN}

Jenis data yang akan digunakan dalam penelitian ini adalah data primer dan data sekunder. Data primer diperoleh dari wawancara kepada para pelaku UMKM sektor pengolahan hasil laut yang ada di wilayah Tegal Barat. Data sekunder akan diperoleh dari browsing di laman Kementerian Koperasi dan UMKM serta dari web lain yang relevan.Teknik pengumpulan data yang digunakan untuk memperoleh data adalah sebagai berikut :

1) Dokumentasi

Menurut Sugiyono (Sugiyono, 2007) dokumen yaitu catatan peristiwa yang sudah berlalu. Dokumen bisa berbentuk tulisan, gambar, atau karyakarya monumental dari seseorang. Dokumentasi dalam penelitian ini akan berupa catatan atas pelaporan keuangan pemerintah pusat.

2) Studi Literatur

Menurut Indriantoro dan Supomo (2002) studi literatur/pustaka yaitu bahan utama dalam penelitian data sekunder. Peneliti memperoleh data yang berkaitan dengan masalah yang sedang diteliti melalui buku, jurnal/literatur, internet dan perangkat lain yang berkaitan dengan analisa laporan keuangan pemerintah pusat.
Model penelitian ini adalah dengan menggunakan model penelitian deskriptif kualitatif. Yaitu teknik menginterpretasikan arti data-data yang telah terkumpul dengan memberikan perhatian dan merekam sebanyak mungkin aspek situasi yang diteliti pada saat itu, sehingga memperoleh gambaran secara umum dan menyeluruh tentang keadaan yang sebenarnya. 


\section{HASIL DAN PEMBAHASAN}

Menurut data statistik Kota Tegal dengan 4 kecamatan dan 27 kelurahan memiliki jumlah penduduk sekitar 236.268 jiw dengan mata pencaharian terbesar yaitu pedagang sebesar 18.267 jiwa atau sebesar $14,40 \%$. Selebihnya adalah buruh, petani, nelayan, PNS dan TNI. Tegal termasuk kota yang berpenduduk padat yaitu 6.136 jiwa/km2.

Kota Tegal yang berada di posisi pesisir pantai utara memanfaatkan sumber daya alam sektor perikanan nya dengan menggunakan 3 (tiga) tempat pelelangan ikan dan tenaga kerja yang digunakan sebanyak 75 orang, terdiri dari 15 tenaga adminstrasi/staf dan manajerian serta 60 orang adalah tenaga harian dengan 6 hari kerja dalam satu minggu sehingga hari kerja yang digunakan selama satu tahun adalah 312 hari atau 52 minggu dalam satu tahun. (UKM, 2010)
Sejak puluhan tahun silam, sebagian masyarakat di pesisir Tegal menggantungkan hidup pada mencari ikan. Berdasarkan data Dinas Kelautan dan Pertanian Kota Tegal tahun 2014, jumlah nelayan di Kota Tegal mencapai 12.589 orang, terdiri dari 630 juragan atau pemilik kapal serta 11.959 buruh nelayan atau anak buah kapal (ABK). Jumlah kapal sebanyak 955 unit, dengan sekitar tujuh jenis alat tangkap, yaitu purseseine, gillnet, trammel net, jaring arad, cantrang, pukat pantai, dan badong. Sejak 2010 hingga 2014, produksi perikanan tangkap di Kota Tegal cenderung fluktuatif, tetapi nilai produksinya terus meningkat. Pada 2010, produksi perikanan tangkap sekitar $20.323,8$ ton dengan nilai $\mathrm{Rp} 135,61$ miliar, produksi pada 2011 sekitar 29.516 ton dengan nilai Rp 198,9 miliar, produksi pada 2012 mencapai $27.170,4$ ton dengan nilai Rp 206,8 miliar. Adapun volume produksi pada 2013 sekitar 23.474 ton dengan nilai Rp 233,1 miliar dan pada 2014 volume produksi perikanan tangkap di Kota Tegal mencapai 25.123,7 ton dengan nilai Rp 255,2 miliar (Nurbiajanti, 2015) 
Tersedianya pasokan ikan hasil laut Kota Tegal yang tidak terserap untuk konsumsi manusia akan mempunyai nilai tambah apabila dijadikan tepung ikan, yang selanjutnya hasilnya diformulasikan dengan bahan bahan lokal lainnya untuk dijadikan pakan ternak. Tepung ikan (marine fish meal) adalah salah satu produk pengawetan ikan dalam bentuk kering, kemudian digiling menjadi tepung. Bahan baku tepung ikan umumnya adalah ikan-ikan yang kurang ekonomis, hasil sampingan penangkapan dari penangkapan selektif, glut ikan (ikan yang melimpah) pada musim penangkapan dan sisa-sisa pabrik pengolahan ikan seperti pabrik pengalengan dan pembekuan ikan dan minyak ikan.

Melihat masih kecilnya pemanfaatan ikan sebagai bahan baku tepung ikan, maka industri tepung ikan memiliki peluang untuk dikembangkan oleh investor di Tegal. Lebih dari itu, komoditas tepung ikan memiliki peluang pemasaran yang prospektif baik untuk pasaran dalam maupun luar negeri. Hingga saat ini, Indonesia merupakan negara pengimpor tepung ikan (Zaqi, 2014)
Salah satu bentuk usaha dalam mengoptimalkan pemanfaatan ikan selain tepung ikan adalah dengan mengembangkan filet dan produk lanjutannya (gel-based products). Filet ikan non ekonomis digunakan sebagai bahan baku produk makanan olahan lanjut antara antara lain seperti baso, sosis, burger, otak-otak, siomay, nugget, empekempek, krupuk ikan dan produk lainnya (Himawan, 2009) Faktor-faktor yang mendorong usaha filet ikan yaitu, banyak diminati masyarakat karena mudah dalam proses pembuatannya, faktor bahan baku yang mudah didapat,faktor tenaga kerja, dan faktor pemasaran yang mudah. Faktorfaktor tersebut merupakan faktor yang berpengaruh dalam keberadaan suatu industri, bidang industri sebenarnya adalah bidang kegiatan yang menimbulkan perubahan yang berdampak luas (Himawan, 2009) 
Pendampingan Usaha Pengolahan Ikan Terintegrasi

Pendampingan UMKM terintegrasi menurut (Wahyudi, 2009) adalah model pengembangan UKM yang menitikberatkan pada upaya perbaikan sistem kelembagaan (capacity building) dan aspek manajerial UKM yang dilakukan secara intensif dan berkelanjutan, dengan melibatkan secara aktif konsultan-konsultan UKM profesional. Konsultan-konsultan tersebut bertugas memberikan nasehat (advisory) dan konsultasi khususnya yang berkaitan dengan kegiatan operasional UKM seharihari.

Keunggulan pendampingan UMKM terintegrasi ini menurut (Wahyudi, 2009) adalah :

1. Pendampingan terintegrasi bersifat lebih proaktif dan intensif. Yang dimaksudkan adalah konsultan pelaksana program secara aktif, dari hari ke hari terjun ke lapangan membantu para pelaku UMKM bersama mencari solusi dari setiap permasalahan UMKM di lapangan.

2. Pendampingan UMKM terintegrasi melakukan pendekatan yang praktis dan aplikatif. Yaitu menerapkan stragegi dan kebijakan konsultan yang dapat langsung diterapkan di lapangan. Sehingga strategi tersebut dapat dilihat keberhasilan nya dan efektifitas nya dalam menyelesaikan permasalahan UMKM.

3. Pendampingan UMKM terintegrasi lebih menekankan pada keberhasilan pendekatan personil, yaitu program pendampingan ini membutuhkan kemampuan konsultan dalam mendekati para pelaku UMKM.

Selain keunggulan dari keunggulan dari kegiatan pendampingan UMKM terintegrasi menurut (Wahyudi, 2009) program pendampingan ini juga memiliki kendala dalam implementasi di masyarakat. Adapun kendala-kendala tersebut adalah :

1. Banyak nya lembaga yang belum menyiapkan tenaga konsultan untuk UMKM. Perguruan tinggi dan lembaga profesi yang melakukan pembinaan terhadap UMKM belum siap dan memiliki kompetensi yang cukup untuk berperan sebagai agent of expertice bagi perkembangan UMKM. Hal itu terbukti dengan kajian penelitain yang dilakukan di tingkat perguruan tinggi lebih banyak pada perusahaan dan bukan UMKM.

2. Selain itu kurikulum pada pendidikan tinggi yang masih belum mennyentuh kebutuhan riil UMKM. 
3. Adanya model pengembangan UMKM yang berifat project based. Dimana program pendampingan UMKM yang dilakukan dengan project based tidak akan menghasilkan penguatan dan pemberdayaan UMKM senyatanya.

Kegiatan pendampingan yang selama ini telah dilakukan oleh beberapa pihak di Kota Tegal adalah sebagai berikut :

Wawancara dengan Ibu D yang telah melakukan usaha Pengolahan ikan berupa nugget ikan di daerah Tegal sari selama kurang lebih 6 tahun :

"Kegiatan pendampingan yang telah dilakukan selama ini di kota Tegal untuk pelatihan di bidang pengolhan ikan biasanya paling dari Dinas Kelautan, Kementerian Kelautan dan Perikanan, dari Dinas Koperasi dan Dinas Tenaga Kerja dan Industri (Disnakerin) dan yang paling baru dari Rumah Kreatif BUMN yang ada di BNI"
Ibu D juga menjelaskan tentang jenis-jenis pelatihan yang selama ini telah dilakukan :

“Pelatihan yang dilakukan selama ini dari Dinas Kelautan berupa penyuluhan dan pelatihan misalnya cara pengolahan ikan dan pemasaran serta pengendalian mutu produk, selain itu juga ada bantuan dari Belanda, pelatihan pengemasan, sertifikat halal dari MUI, BPOM, dan pelatihan tentang mutu pangan. Sedangkan dari Rumah Kreatif BUMN pelatihan bermacam-macam berupa branding produk, dan berbagai macam pelatihan yang menunjang pemasaran. Dari Dinas Koperasi juga ada pelatihan berupa pendampingan pembuatan badan hukum pendirian koperasi bagi pengolah ikan. Sedangkan dari Disnakerin biasanya berupa pelatihan pengolahan ikan serta gelar produk IKM mbak” 
Ketika ditanya tentang kemanfaatan dari kegiatan pelatihan tersebut selama ini serta keterkaitan nya antara satu dengan yang lain, ibu D menjawab :

“ Sebenarnya kegiatan satu dengan yang lain menguatkan antara satu dengan yang lain, dampak bagi pengembangan produk juga banyak mbak...tapi kita butuh adanya pola pendampingan yang baik secara terstruktur dan berkesinambungan serta progres yang tercatat. Akan tetapi pada prakteknya sulit karen masing-masing kedinasan punya kebijakan sendiri-sendiri”
Selain itu tanggapan dari seorang pengusaha ikan berupa olahan ikan frozen bernama $\mathrm{W}$ juga hampir sama yaitu :

“ Pelatihan yang ada selama ini masih dibutuhkan karena kami butuh informasi tentang penyimpanan hasil olahan ikan yang lebih baik dan tidak cepat busuk"

Pelatihan yang ada selama ini diketahui dari siapa saja Ibu W menjawab :

"Pelatihan selama ini biasanya dari dinas Koperasi berupa pendampingan terutama tentang packing produk, pendampingan tersebut sangat bermanfaat untuk pengembangan usaha pengolahan ikan frozen kami. Tapi kami berharap pelatihan dilakukan secara bersambung dari pembuatan produk hingga bazar atau gelar produk"

\section{Rumusan Pendampingan UMKM}

Terintegrasi

Pendampingan UMKM yang terintegrasi dapat di rumuskan sebagai berikut :

1. Pendampingan UMKM yang terarah dari mulai pembuatan produk hingga pemasaran.

Pendampingan terintegrasi berupa pelatihan yang diberikan kepada para UMKM mulai dari proses pembuatan produk, manajemen keuangan hingga ke pemasaran. Pelatihan tersebut sebaiknya dilakukan dengan berjenjang 
dan masing-masing UMKM di data perkembangan nya.

2. Pendampingan yang terdokumentasi dengan baik sehingga jelas tahapan perkembangan dari UMKM.

Dokumentasi atau data dari masingmasing UMKM di butuhkan sebagai alat pemantauan dari pihak yang berkepentingan untuk dapat melihat kondisi dan perkembangan UMKM.

3. Dapat dilakukan oleh beberapa instansi / lembaga yang memberikan edukasi kepada para UMKM yang mempunyai kesamaan visi mengembangkan UMKM.

Kesamaan visi dan misi ini diharapkan juga ada kesamaan langkah untuk menciptakan UMKM Kota Tegal yang lebih berdaya dan berkembang ke tahap yang lebih baik.

4. Adanya indikator tahapan UMKM dalam setiap tahapan perkembangan pembinaan.

Rumusan indikator perkembangan UMKM saat ini belum ada sehingga belum dapat diketahui tahapan atau kondisi UMKM yang membutuhkan treatment tertentu atau semacam Training Needs Assesment. Sehingga UMKM terkadang mendapat kan pelatihan yang tidak dibutuhkan atau kurang mengena dengan apa yang dibutuhkan.

\section{SIMPULAN}

Kegiatan pelatihan yang berkesinambungan dari mulai pembuatan produk, managemen keuangan hingga pemasaran amat penting dilakukan oleh pihak-pihak yang terkait dalam edukasi UMKM. Terlebih lagi apabila kegiatan tersebut dapat terdata dengan baik, sehingga dapat diketahui berapa UMKM dan di tahapan mana para UMKM tersebut berada, apakah masih berkutat pada pengolahan produk ataukah sudah membutuhkan pengelolaan manajemen atau pemasaran.

Hal tersebut penting untuk dilakukan karena UMKM adalah salah satu tonggak perekonomian yang berpengaruh terhadap kondisi ekonomi masyarakat di Indonesia.

Perlu diadakan sebuah forum diskusi diantara lembaga atau instansi yang bergerak di bidang edukasi kepada para UMKM untuk memberikan kesatuan tujuan dan arah gerak bagi UMKM bidang pengolahan ikan pada khususnya dan UMKM secara umum di kota Tegal agar dapat lebih cepat berkembang dan mencapai target percepatan pertumbuhan ekonomi di kota Tegal. 


\section{DAFTAR PUSTAKA}

Ardiana. (2010). Kompetensi SDM UKM dan Pengaruhnya Terhadap Kinerja UKM di Surabaya. Jurnal Manajemen Dan Kewirausahaan.

Ashariyadi. (2016). Geliat UMKM di Era MEA. Masyarakat Asean, 4-5.

Himawan, G. Y. (2009). PEMETAAN PERSEBARAN INDUSTRI FILET IKAN DI KELURAHAN TEGALSARI KECAMATAN TEGAL BARAT BERBASIS SISTEM INFORMASI GEOGRAFIS ( SIG ).

Nurbiajanti, S. (2015, April 13). Potensi Bahari di Pantai Utara. Retrieved from

https://ekonomi.kompas.com/read/20

15/04/13/192000226/Potensi.Bahari.d i.Pantai.Utara.

Sudaryanto, Ragimun, \& Wijayanti, R. R. (2014). Strategi Pemberdayaan UMKM Menghadapi Pasar Bebas Asean. Www.Kemenkeu.Go.Id, 1-32. Retrieved from http://www.perpustakaan.depkeu.go.i d/FOLDERJURNAL/2014_kajian_pk em_Strategi Pemberdayaan UMKM.pdf.

Sugiyono. (2007). Metode Penelitian Bisnis.

Tedjasuksmana, B. (2014). Potret Umkm Indonesia Menghadapi Masyarakat
Ekonomi Asean 2015. The 7th NCFB and Doctoral Colloquium 2014 Towards a New Indonesia Business Architecture Business And Economic Transformation Towards AEC 2015, 189-202.

UKM, B. (2010). Prospek Pengolahan Tepung Ikan di Kota Tegal. Retrieved from https://bisnisukm.com/potensiperikanan-di-kota-tegal.html

Wahyudi, I. (n.d.). PROGRAM PENDAMPINGAN

TERINTEGRASI Alternatif Solusi Kendala Non-Modal bagi UKM 1).

Wahyudi, I. (2009). PROGRAM PENDAMPINGAN

TERINTEGRASI Alternatif Solusi Kendala Non-Modal bagi UKM. Retrieved from https://iyuk.wordpress.com/2009/04/1 1/program-pendampingan-ukmterintegrasi/

Zaqi. (2014). Tepung Ikan. Retrieved October 4, 2018, from http://www.tegalkota.go.id/v2/index.p $\mathrm{hp} /$ investasi/peluang-usaha/22tepung-ikan 